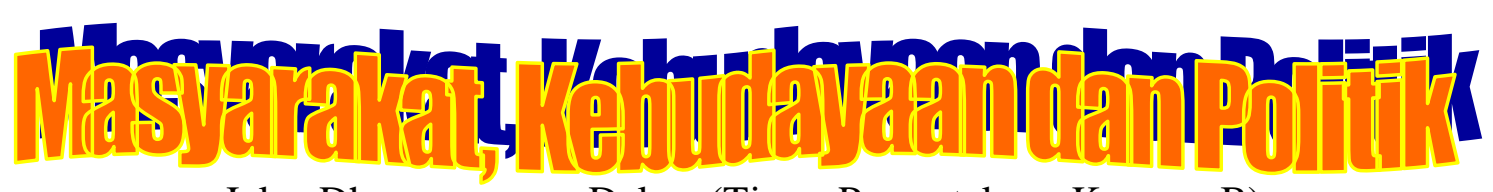

Jalan Dharmawangsa Dalam (Timur Perpustakaan Kampus B)

Universitas Airlangga, Surabaya, East Java, Indonesia 60286

Telephone: (+6231) 5017429, Fax: (+6231) 5012442, E-mail: mkp@journal.unair.ac.id

Website: http://e-journal.unair.ac.id/MKP

Surabaya, 7 July 2020

Title:

Kebijakan pelayanan kesehatan reproduksi bagi perempuan penyandang disabilitas dalam rangka pencegahan kekerasan seksual

\title{
Author:
}

Tri Joko Sri Haryono, Toetik Koesbardiati, Siti Mas'udah

\section{Retraction Note:}

This article has been retracted. The retraction decision was made by the editor upon finding that there are some writing errors in the article.

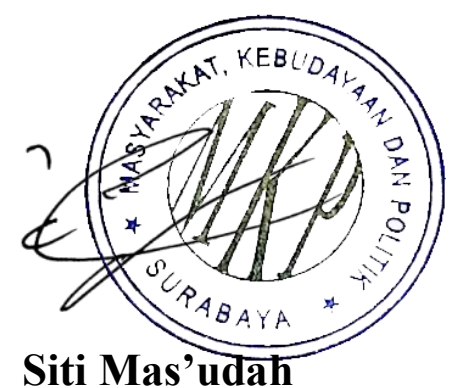

Chief Editor of Masyarakat, Kebudayaan dan Politik Journal 